\title{
Vermicomposting Using Waste Papers as Substrates for African Night Crawler (Eudriluseugeniae)
}

\author{
Yolina T. Castaňeto ${ }^{1}$, Elmer T. Castaňeto ${ }^{2}$ \\ ${ }^{1}$ Nueva Vizcaya State University College of Forestry, Bayombong, Nueva Vizcaya Philippines \\ ${ }^{2}$ Nueva Vizcaya State University Center for Environmental Resources Management and Sustainable Development (CERMSD) \\ Bayombong, Nueva Vizcaya Philippines
}

\begin{abstract}
As part of the implementation of Solid Waste Management Program, accumulating volumes of waste paper generated is everybody's concern. Proper waste disposal and segregation should be done. Thus, a research was conducted utilizing the different waste papers as substrates for African night crawler (Eudriluseugeniae). The objective of the study is to determine which among the different waste papers is the best substrate for African night crawleras compared with those fed by agricultural wastes. The study was conducted using Completely Randomized Design. Results revealed significant differences in the change in weight of African night crawler, weight of waste paper consumed, weight of vermicompost produced, number of eggs and number of juveniles produced by the African night crawler after feeding with the different waste papers. Feeding the African night crawler with carton and bond paper resulted in significant increase in weight of African Night Crawler, number of juveniles, weight of consumed paper and weight of vermicompostproduced. On the other hand, the combined agricultural wastes gave the highest number of eggs produced. Therefore, waste papers such as carton, bond paper and newsprints can be used as feeding materials for African night crawler. Carton and bond paper were the best substratesover newsprint for improved vermicompost produced, increase in African night crawler biomass, weight of vermicompost produced and number of juveniles.
\end{abstract}

Keywords: vermicomposting, Eudriluseugeniae, African night crawler, waste paper, substrates

\section{Introduction}

Over the years, garbage problems in the country are considered one of the serious problems both in the rural and urban setting. The improper and indiscriminate disposal of wastes has compounded the problem. As a solution to this, Republic Act 9003 (Ecological Solid Waste Management Act) was enacted to help lessen the problems in waste handling and disposal. Proper segregation of wastes is an important component embodied in the guidelines. Sad to note, that inspite of the efforts to implement and solve the problem in waste segregation, many do not follow and cannot internalize the changes on waste segregation. This scenario makes it difficult for the implementorto successfully implement and follow guidelines contained in the Ecological Solid Waste Management Act. The indifferent attitude and reluctance of the populace make it difficult for the implementor to gain success in solving problems on waste management.

In Nueva Vizcaya State University, as an academic institution serious efforts were done to implement the guidelines in the solid waste management act. In fact, the University has a unit assigned to take good care of the wastes generated within the campus. However, full success has not beenattained because of the attitude of some stakeholders.

The University generates agricultural wastes from the different projects and waste papers from different offices. In support to the problem on wastes management, the Center for Environmental Resources Management and Sustainable Development (CERMSD) has initiated vermicomposting utilizing wastes from the different projects. It is now in full swing and also contributes modest amount to the university for sale of vermicompost. However, it was also observed that there were accumulating volumes of different wastes papers generated in different offices within the campus. These wastes need immediate attention and recycling them is necessary for more efficient utilization instead of throwing or burning them. Moreover, burning of wastes is prohibited under the ecological solid wastes management act because of its hazards to the environment and to humans. Furthermore, backyard burning or simply burning of garbage releases toxic air pollutants which leads to respiratory diseases like asthma, bronchitis, lung cancer, and even death [4].

To provide solution on this problem, this study sought to find a positive and useful way in recycling wastes paper through vermicomposting. Vermicomposting is a method of composting using earthworms to turn organic wastes into very high quality compost [2]. The paper wastes served as feeding materials to E. eugeniae, a composting earthworm and considered the most efficient vermicomposting species. Thus, this study in vermicomposting using different waste papers as substrate is very necessary for proper waste management.

\section{Objectives}

The general objective of the study was to determine which among the different waste papers is the most preferred by the African Night Crawler (Eudriluseugeniae)for vermicomposting. Specifically the study aimed to:

1. Determine if there are significant differences on the weight of vermicompost produced, weight of waste papers consumed, change in weight of African night crawler, number of eggs and juveniles produced by $E$. eugeniaewhen fed with cartons, bond paper and newsprint; and 


\section{International Journal of Science and Research (IJSR) \\ ISSN (Online): 2319-7064}

Index Copernicus Value (2013): 6.14 | Impact Factor (2015): 6.391

2. determine which type of waste paper is the best substrate for E. eugeniae.

\section{Methodology}

The study was conducted for five months at the Center for Environmental Resources Management and Sustainable Development(CERMSD), Nueva Vizcaya State University Bayombong, Nueva Vizcaya, Philippines.

Two kilograms of African night crawler were procured from Bay, Laguna Philippines and were temporary fed with mixed agricultural wastes while waiting for the date of the experiment and also for acclimatization for one month. Waste papers were collected within the campus while hog manure was collected in the Swine Project of the university.

A $1 \mathrm{~m} \times 5 \mathrm{~m}$ concrete vermicomposting bed was prepared for the experiment, which was divided into twelve compartments for the different treatments following the experimental layout of the study. The flooring of the vermicomposting beds were lined with sacks.

\section{Preparation of Feeding Materials}

The control treatment was prepared using 20kgs (dry weight) of combined rice hay and grass clippings mixed with dried and ground hog manure. Tap water was added to the mixture to maintain $60 \%$ moisture and was set aside and covered with plastic for two weeks for predecomposition process. After two weeks the preparation for other treatments was done. Three types of waste papers namely: cartons, bond paper and newsprints were used. Ten kilograms (dry weight) each of cartons, bond paper and newsprints were shredded using a shredder. Thirty kilograms (dry weight) of hog manure was dried and ground. Mixture of each feeding materials was $10 \mathrm{kgs}$ of the waste paper (carton, bond paper and newsprint) was added with $10 \mathrm{kgs}$ of hog manure. After mixing the feeding materials, tap water was added to the mixture to maintain the $60 \%$ moisture requirements. The following were the corresponding proportions of feeding materials per treatment:

1) $\mathrm{T}_{1}-20 \mathrm{kgs}$ of predecomposed rice hay, grass clippings and hog manure (Control)

2) $\mathrm{T}_{2}-10 \mathrm{kgs}$ of shredded cartons and 10kgs of dried, pounded hog manure

3) $\mathrm{T}_{3}-10 \mathrm{kgs}$ of shredded bond paper and $10 \mathrm{kgs}$ of dried, pounded hog manure

4) $\mathrm{T}_{4}-10 \mathrm{kgs}$ of shredded newsprint, and $10 \mathrm{kgs}$ of dried, pounded hog manure.

The experiment was laid out in a Completely Randomized Design (CRD) replicated four times. All treatments were added with water to maintain the $60 \%$ moisture requirements of the substrates. The prepared substrates per treatment was divided into four for replications 1, 2, 3 and 4 and placed in a cemented compost bin based on the lay-out of the study. One hundred grams (100 g) of E. eugeniae were placed in each compartment with the prepared feeding materials. The set-up was covered with black net for protection and watering was done as needed. Thirty days after stocking of African night crawler the experiment was terminated. Data on weight of vermicompost produced, the weight of waste papers consumed, change in weight of African night crawler, number of juveniles and eggs of E. eugeniaewere gathered and subjected to F-test using the Analysis of the Variance. The gathered data was analyzed using the SPSS 11.5 Statistical program.

\section{Results and Discussion}

African Night Crawler (Eudriluseugeniae) is a composting earthworm and efficient in converting wastes into vermicompost. This study determined if there are significant differences in the vermicompost produced using different types of waste papers as substrate compared with combined agricultural wastes.Results of the Analysis of the Variance (ANOVA) revealed significant differences on the weight of vermicompost, weight of consumed waste paper, change in weight of African night crawler (ANC), number of juveniles and number of eggs of African night crawlers.

\section{Weight of vermicompost}

The weight of vermicompost produced by African night crawler after feeding with different types of waste papers as substrate was found significant. The weight of vermicompost obtained using different waste papers as feeding materials to African night crawler were higher (2943 g, 3199 g and 2872 g) than those fed with agricultural wastes $(1800 \mathrm{~g})$ and served as the control (Figure 1). There was an increase in the amount of vermicompost produced of $63.5 \%$ for carton (T2), $77.72 \%$ for bond paper (T3) and $59.56 \%$ for newsprint (T4).

The study conducted by Afidchao et al. (2007) also revealed significant differences on the amount of vermicast produced by African night crawler when fed with different types of agricultural wastes [1]. On the contrary, study conducted by Paraguas et al. (2013) using different types of waste papers as feeding materials did not yield significant different on the amount of vermicast produced by the African night crawler [3].Similarly, in another study conducted by Lagrio (2007)using different ratios of mushroom spent as feeding materials to E. eugeniaedid not give significant differences on the amount of vermicast produced by the African night crawler [2].

Figure 1: Weight of vermicompost produced by E. eugeniae 


\section{International Journal of Science and Research (IJSR) \\ ISSN (Online): 2319-7064}

Index Copernicus Value (2013): 6.14 | Impact Factor (2015): 6.391

Weight of waste paper consumed

The E. eugeniae preference for the different types of papers used in the study as shown in the amount of waste paper consumed differs significantly.Among the three waste papers fed, carton gave the highest consumption (4788.75 g) while newsprint had the lowest $(901.44 \mathrm{~g})$ and the least preferred by E. eugeniae. Mixed agricultural wastes, carton and bond paper were most preferred by E. eugeniae over newsprint (Figure 2). This might be due to the ink used in the newsprint which make it less preferred by the African night crawler worms. Similarly, significant differences were also observed in a study using different waste papers fed to $E$. eugeniae[3]. those fed with mixed agricultural wastes (T1) and those fed with bond paper (T3).

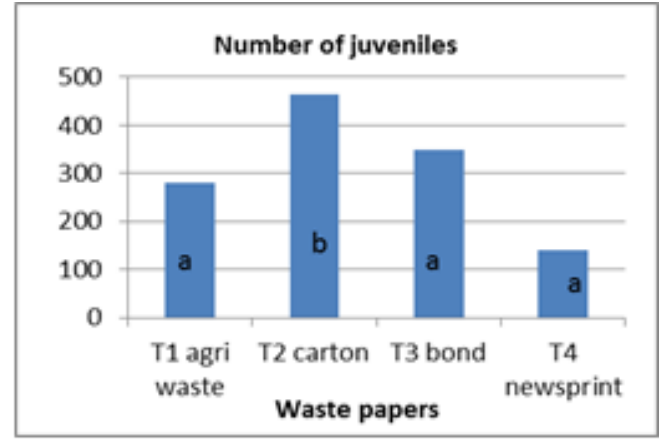

Figure 4: Number of juveniles of E. eugeniae

\section{Number of eggs produced}

The reproductive potential of African night crawler being a polyembyonic species was found affected by the feeding materials given. Feeding them with mixed agricultural wastes (308) resulted in the highest number of eggs produced but was comparable with those fed with carton (118) and bond paper (198). African night crawler fed with newsprint (50) had the lowest number of eggs produced.

Figure 5: Number of eggs produced by E. eugeniae

\section{Conclusion and Recommendation}

Waste papers like cartons, bond papers, newsprints can be used as feeding materials for E. eugeniae. Significant differences in weight of vermicompost produced, weight of consumed waste paper, change in weight of African night crawler, number of juveniles and number of eggs produced by the African night crawler after feeding with the different waste papers as substrates. African night crawler with carton and bond paper as substrates resulted in significant increase in the weight of vermicompost produced, weight of consumed paper, change in weight of the earthworms and number of juveniles. On the other hand, combined agricultural waste gave the highest number of eggs produced.

Findings revealed that waste papers such as carton, bond paper and newsprints can be used as feeding materials for African night crawler. Based on the findings of the studyvermicomposting using carton and bond paper as substratesresulted in an improved biomass production of

Volume 5 Issue 6, June 2016 www.ijsr.net 
African night crawler, increase in vermicompost produced and increase in the weight of waste papers consumed and number of juveniles. However, it is suggested that combination of different ratios of waste papers as substrate should also be explored as well as the evaluation and analysis of their nutrient contents.

\section{References}

[1] S.K. Afidchao, Y.T. Castaneto, E.T. Castaneto,"Agricultural Wastes as Feed Materials for African night crawler (Eudriluseugeniae)," NVSU Research Journal, XIV (1-2), pp. 54-59, 2007.

[2] S.D. Lagrio, Effectiveness of African night crawler (Eudriluseugeniae) as Vermicomposting Agent to Different Proportions of Mushroom Spent, Undergraduate Thesis. Nueva Vizcaya State UniversityBayombong, Nueva Vizcaya, 2007.

[3] W.G. Paraguas, Y.T. Castaneto, E.T Castaneto, "Different Waste Papers as Feeding Materials for African night crawler (Eudriluseugeniae)," NVSU Research Journal, XX (2), pp. 68-71, 2013.

[4] (http://en.wikipedia.org/wiki/Recycling).

\section{Author Profile}

Yolina T. Castaneto is a product of the University of the Philippines Los Banos (UPLB) College, Laguna Philippines for her BSForestry, MS and Ph.D. degrees. She is at present a Professor at the Nueva Vizcaya State University Bayombong, Nueva Vizcaya Philippines. She is actively involve in instruction, research and extension in the university.

Elmer T. Castaneto took his Master in Forestry at UPLB College Laguna Philippines. He is a Professor and at present the Director of the Center for Environmental Resources Management and Sustainable Development (CERMSD) at Nueva State University Bayombong, Nueva Vizcaya Philippines. He is actively involve in instruction, research and extension in the university. 